\title{
ТЕОРІЯ ТА ПРАКТИКА УПРАВЛІННЯ ЯКІСТЮ В ІСТОРИЧНІЙ РЕТРОСПЕКТИВІ ТА ЇХ ВПЛИВ НА СУЧАСНІ КОНЦЕПЦІї УПРАВЛІННЯ ЯКІСТЮ
}

\section{THEORY AND PRACTICE OF QUALITY MANAGEMENT IN HISTORICAL RETROSPECTIVE AND THEIR INFLUENCE ON MODERN CONCEPTS OF QUALITY MANAGEMENT}

\author{
Русавська Валентина Андріївна \\ кандидат історичних наук, профессор, \\ Київський національний університет культури і мистецтв \\ ORCID: https://orcid.org/0000-0002-2741-6597 \\ Таран Марина Дмитрівна \\ магістрантка, \\ Київський національний університет культури і мистецтв \\ ORCID: https://orcid.org/0000-0003-2332-6698
}

Rusavska Valentyna, Taran Maryna

Kyiv National University of Culture and Arts

Стаття присвячена теорії та практиці управління якістю, яка за свій історичний розвиток пройшла низку етапів, кожен з яких має свої особливості та закономірності. Проаналізовано і хронологічно викладено етапи розвитку управління якістю, сорормульовано їх зміст та результати отримані внаслідок застосування методології кожного з етапів. Досліджено сутність та призначення класичних моделей управління якістю, що є результатами грунтовної наукової праці зарубіжних вчених, що мали вирішальний вплив на сучасну теорію і практику забезпечення якості та лягли в основу концепції якості і стали класичними. Окреслено перспективні вектори розвитку управління якістю в мінливих умовах сучасного ринку товарів та послуг, що ґрунтуються на дотриманні вимог міжнародних стандартів серії ISO, що охоплюють питання сучасної методології менеджменту якості на підприємствах та на виконанні принципів системи управління безпечністю харчової продукції НАССР.

Ключові слова: якість, управління якістю, контроль якості, якість продукції, якість послуг, управління якістю продукції та послуг.

Статья посвящена теории и практике управления качеством, что в своем историческом развитии прошли ряд этапов, каждый из которых имеет свои особенности и закономерности. Проанализированы и хронологически изложены этапы развития управления качеством, сорормулированы их содержание и результаты полученные в результате применения методологии каждого из этапов. Исследована сущность и предназначение классических моделей управления качеством, что являются результатами основательной научной работы зарубежных ученых, оказавших влияние на современную теорию и практику управления качеством, легли в основу концепции обеспечения качества и стали классическими. Определены перспективные векторы развития управления качеством в изменчивых условиях современного рынка товаров и услуг, основанных на соблюдении требований международных стандартов серии ISO, охватывающих вопросы современной методологии менеджмента качества на предприятиях и в выполнении принципов системы управления безопасностью пищевой продукции НАССР.

Ключевые слова: качество, управление качеством, контроль качества, качество продукции, качество услуг, управление качеством продукции и услуг.

The article is devoted to the theory and practice of quality management which in its historical development has gone through several stages, each of which has its own characteristics and patterns of development, which are tracked in the service and production activities of domestic and foreign enterprises. After all, the main purpose of all stakeholders involved in the production, circulation and supply of food and services is to guarantee consumers the safety and quality of food and services provided. Therefore, the issue of continuous work on improving the quality level for the ability to compete in the market and get the desired amount of profit is relevant and needs to be studied. Methods: methods of analysis, synthesis, induction, deduction, generalization, graphical, forecasting. Results. Determined peculiarities and 
regularities of development of quality management stages, formulated the content of this stages. Presented the results of application of the methodology of each of the stages that gave impetus to further improvement of quality management tools. Studied the essence and purpose of classical models of quality management. The quality management models considered in the article are the results of thorough scientific work of foreign scientists, who had a decisive influence on modern theory and practice of quality assurance and formed the basis of the concept of quality and became classical. Outlined promising vectors of quality management development in the changing conditions of the modern market of goods and services. The selected vectors of quality management are based on compliance with the requirements of international standards of the ISO series, and on the implementation of the principles of food safety management system HACCP. The practical value of this theoretical study lies in the definition of promising vectors of quality management, based on the experience gained in the process of historical retrospective development of quality management. The selected areas of quality management can be further used in quality management and service management, and the integration of innovative methods of product and service quality management in traditional approaches to product and service quality management will improve the quality of service and production activities of market operators as a whole.

Keywords: quality quality management, quality control, product quality, service quality, product and service quality management.

Постановка проблеми. Управління якістю було одним з ключових завдань на кожному етапі еволюційного розвитку галузі виробництва продукції, торгівлі та сорери послуг, тому, удосконалення управління якістю $€$ актуальним питанням і для сучасних операторів ринку товарів та послуг. Адже, враховуючи зростаючі потреби споживачів у мінливих умовах сьогодення, формується необхідність у забезпеченні стабільно високого рівня якості та безпечності продукції та послуг, що реалізуються, саме з цією метою і продовжується робота над удосконаленням процесів управління якістю. Наразі, існує потреба у формулюванні нових концепцій та створенні нових методик, що будуть базуватися на багаторічному світовому досвіді з управління якістю та водночас дозволять інтегрувати в них новітні підходи та інструменти управління якістю.

Аналіз останніх досліджень і публікацій. Фундаментальні положення щодо визначення сутності якості, особливостей та проблем управління якістю продукції та послуг, створення та впровадження систем управління якістю продукції та послуг на підприємствах сорормували наукові праці таких відомих зарубіжних вчених як: Е. Демінга, К. Ісікави, Дж. Джурана, А. Фейгенбаума, Г. Тагучі, Ф. Кросбі, У. Шухарта, А. Субетто, М. Мексона, М. Альберта, Ф. Хедоурі та інших. Наукові праці цих вчених стали класичним підгрунтям для формування нових методів та концепцій управління якістю, що розробляються в наш час.

Виділення невирішених раніше частин загальної проблеми. Незважаючи на численні наукові здобутки у дослідженні питання управління якістю як зарубжними вченими так і вітчизняними науковцями, слід відзначити недостаність напрацювань щодо окреслення перспективних векторів управління якістю в мінливих умовах сьогодення, що грунтувались би на аналізі етапів розвитку та досвіду управління якістю в історичній ретроспективі з врахуванням особливостей та закономірностей їх розвитку, що формує необхідність у проведенні додаткових наукових досліджень в даному напрямку.

Формулювання цілей статті. Метою даної статті $\epsilon$ аналіз сутності та особливостей розвитку етапів управління якістю в історичній ретроспективі, та окреслення перспективних напрямків управління якістю в сучасних умовах сервісно-виробничої діяльності операторів ринку товарів та послуг.

Виклад основного матеріалу дослідження. Теорія та практика управління якістю у своєму історичному розвитку пройшла декілька етапів, кожен з яких має свої особливості та закономірності фрормування. Нижче розглянуто сутність кожного з основних етапів розвитку управління якістю.

1. Індивідуальний контроль якості використовувався на підприємствах до кінця XIX ст. Відповідальними за виготовлення продукції були один працівник або група, що могли самостійно контролювати результати своєї виробничої діяльності, їх робота була визначена заданими моделями у вигляді рисунків, креслень, шаблонів і т.п., що свідчило про перехід підприємств від ремісничого до індустріального етапу виробництва, оскільки для останнього характерним було те, що якість відповідала спроможності працівників аналізувати відповідність результатів своєї роботи заданим моделям.

2. Цеховий контроль якості зародився на початку XX ст., поштовхом до чого був розвиток промисловості та більш глибокий розподіл праці в середині виробничого процесу підприємств. Відповідальність за якість розподілялася між окремими працівниками та керівниками цехів, останні відповідали за якісний результат роботи цеху та визначали загальні вимоги до якості продукції. 
Підґрунтям цехового контролю були принципи наукового управління якістю запропоновані всесвітньо відомий американським основоположником наукової організації праці та менеджменту Ф. Тейлором, їх головним завданням було задати допуск на показники якості продукції (встановлення верхньої та нижньої межі допустимої якості та пропусних і непропускних колібрів), здійснити виміри його значення і таким чином розсортувати продукцію на десректу та придатну до використання, залежно від потрапляння показника у допуск. Проте, поняття «норма якості», «допуск», «десрект» мали відношення тільки щодо окремих виробів (деталей, вузлів), не охоплюючи технологічні процеси виробництва та партії продукції в цілому.

3. Приймальний контроль якості почали використовувати на підприємствах в першій половині XX ст., оскільки впровадження масового виробництва та збільшення об'ємів випускної продукції стали поштовхом до відокремлення технічного контролю від виробничих операцій. На промислових підприємствах організовувалися відокремлені служби технічного контролю (штатні контролери та їх керівник, що підпорядковувався керівництву підприємства).

4. Статистичний контроль якості став рішенням проблеми забезпечення якості виробничих процесів на підприємствах. Вже на початку XX ст. всесвітньо відомий американський вчений У. Шухарт та американський фрахівець в області якості, академік Міжнародної академії якості Дж. Джуран розробили та впровадили на практиці статистичний метод контролю якості, що грунтувався на використанні контрольної карти 3 межами регулювання (карти Шухарта). Передбачалося послідовне нанесення на спеціальну карту результатів замірів у вигляді середніх значень, на основі яких розроблялася серія грасрічних зображень, із змінами, що відбувалися у процесі, це допомагало визначити вихід параметрів за межі статистичних контрольних меж та виявлення невипадкових відхилень.

Також даний етап характеризується переходом від загального контролю якості до вибіркового контролю якості, під час останнього у процесі виробництва на підприємстві відбиралися згідно плану контрольні дані, котрі в подальшому оброблялися методом математичної статистики. Проте, даний вид контролю поширювався повільними темпами, контроль якості здійснювався у межах цехів та не міг вирішити суттєвих проблем якості на підприємствах.

5. Технічний контроль якості активно використовувався у 60-х рр. XX ст. Для досягнення необхідного рівня якості продукції на підприємствах, були створені нові структури служб технічного контролю, що орієнтувалися на мінімізацію витрат на якість продукції за умов збереження енерго- та матеріало ємності та на підвищення обсягів виготовленої продукції. Контроль якості став сфрерою спеціалізованої діяльності, зорієнтованої на регулювання якості, проведення аналізу та виявлення причин десректів продукції, розробку заходів 3 ліквідації виявлених десректів та проведення превентивних заходів, для чого стали створюватись спеціальні служби управління якістю.

Вже наприкінці 40-х рр. XX ст. конкурентне середовище стало жорсткішим, темпи науково-технічного прогресу стрімко зростали, що спонукало управлінців промисловості по іншому поглянути на якість продукції. Таким чином, був здійснений логічний перехід від традиційного контролю якості продукції до управління цією якістю, що стало принципово новим явищем, адже підприємства ставили перед собою завдання розробки та впровадження превентивних дій для попередження виникнення десректів продукції, а не виявлення цих десректів у момент виробництва.

6. Комплексне управління якістю набуло поширення у 60-ті рр. XX ст., автором концепції став американський експерт з контролю якості А. Фейгенбаум. Метою нової концепції стала орієнтація всієї системи заходів на підприємстві на досягнення того рівня якості продукції, який був запланований, даний підхід акумулював в собі елементи технічного та організаційного керівництва, що дало можливість підвищити рівень якості продукції та одночасно зменшити витрати на неї. Комплексне управління якістю було доповненням для статистичних інструментів контролю якості у вигляді методів накопичення інформації про якість, стандартизацію, сертисрікацію, мотивацію праці та ін.

7. Концепції TQC (Загальний контроль якості) у США та CWQC (Управління якістю у межах усієї компанії) у Японії були ссрормульовані у 60-70-х рр. XX ст. та спиралися на загальну методологію комплексного управління якістю, виступаючи як нові специсрічні організаційні підходи до управління якістю на рівні підприємства. Концепція TQС являла собою систему управління якістю, що розповсюджується на всі напрямки діяльності підприємств, та передбачає вирішення проблеми якості на підприємстві не лише керівними ланками, а й структурованими адміністративними підрозділами, що спеціалізуються виключно на ссрері забезпечення якості продукції на підприємстві. 
Концепція CWQC грунтувалася на участі у роботі по забезпеченню якості продукції на підприємстві всього персоналу від вищого керівництва до рядового робітника, відповідно кожен повинен володіти знаннями та навичками щодо методів управління якістю, передбачалося застосування статистичних методів, створення та робота на підприємствах гуртків якості, організація внутрішньоорганізаційних перевірок існуючої на підприємстві системи якості.

8. Забезпечення якості на базі стандартів ISO 9000 розпочалося в кінці 80-х рр. XX ст. Згідно з новою методологією на підприємствах створюються результативні та есрективні системи управління якістю, що відповідають положенням вище зазначених міжнародних стандартів та виступають своєрідною гарантією максимального задоволення існуючих вимог споживачів. 3 90-х рр. XX ст. створюються галузеві версії міжнародних стандартів у сфері якості, здійснюється розробка міжнародних стандартів серії ISO серії 14000, в положеннях котрих зафріксовано вимоги, до системи екологічного управління якістю на підприємствах.

Даний етап також характеризується активним застосуванням на підприємствах концепції Загального управління якістю (TQM), основні принципи котрої покладено в основу міжнародних стандартів ISO серії 9000, а також в основу моделі самооцінки діяльності організацій на відповідність критеріям премій з якості.

9. Інтегровані системи управління якістю характеризуються тенденцією до розвитку на початку XXI ст. та грунтуються на синтезуванні

\begin{tabular}{l}
\hline 1. індивідуальний контроль якості \\
\hline 2. цеховий контроль якості \\
\hline 3. приймальний контроль якості \\
4. статистичний контроль якості \\
5. технічний контроль якості \\
6. комплексне управління якістю \\
7. концепції ТQС, СWQС \\
8. забезпечення якості на базі стандартів ISO 9000 \\
9. інтегровані системи управління якістю \\
\hline
\end{tabular}

\section{Схема 1. Етапи історичного розвитку управління якістю}

Джерело: розроблено авторами на основі [3, c. 120-127] різних моделей систем управління якості (ISO 9000, ISO 14000, галузеві версії міжнародних стандартів у сорері управління якістю, системи НАССР), що використовуються на підприємствах. Розвиток цієї тенденції свідчить про активізацію інтеграції системи управління якістю у загальну систему управління якістю підприємств 3 метою підвищення іï едрективності та результативності.

Підсумовуючи результати дослідження, розроблено схему 1 , на якій в хронологічному порядку зазначено основні етапи розвитку управління якістю.

Отже, аналізуючи етапи історичного розвитку управління якістю, можна ствердити, що на розвиток теорії та практики управління якістю мали вплив наукові здобутки великої кількості зарубіжних фрахівців з управління якістю. Нижче розглянуто основні положення їх робіт та наведено приклади моделей управління якістю, що стали вагомим внеском в історію розвитку управління якістю.

Розробка американським вченим Ф. Тейлором принципів наукового управління. В своїй історичній ретроспективі шлях розвитку управління якістю розпочинається 3 першої половини XIX ст., стимулом для чого слугували наукові праці про принципи наукового управління американського вченого, основоположника наукової організації праці та менеджменту Ф.Тейлора, який трактує процес управління якістю як чергування таких етапів, як планування - реалізація - контроль.

Використання статистичних методів американського вченого У. Шухарта в процесі виробництва. У першій половині XX ст. американський вчений та засновник статистичного методу якості У. Шухарт, доповнив створений американським вченим Ф.Тейлором процес етапом - «коригуючі дії». У. Шухарт застосував статистичні методи для процесів виробництва, статистично пояснив зміни процесу виробництва у часі, створивши контрольні карти. Основним вектором стало дослідження процесів виробництва з зменшенням змін у ньому за допомогою здійснення аналізу інформації, що зазначена в контрольних картах. Найбільш істотною характеристикою розповсюдження статистичного контролю якості став перехід від суцільного контролю до вибіркового (див. рис. 1).

Виникнення системного підходу до управління якістю запропонованого Е. Демінгом (14 принципів Демінга). Праці американського вченого У. Шухарта здійснили вагомий вплив на діяльність американського вченого 


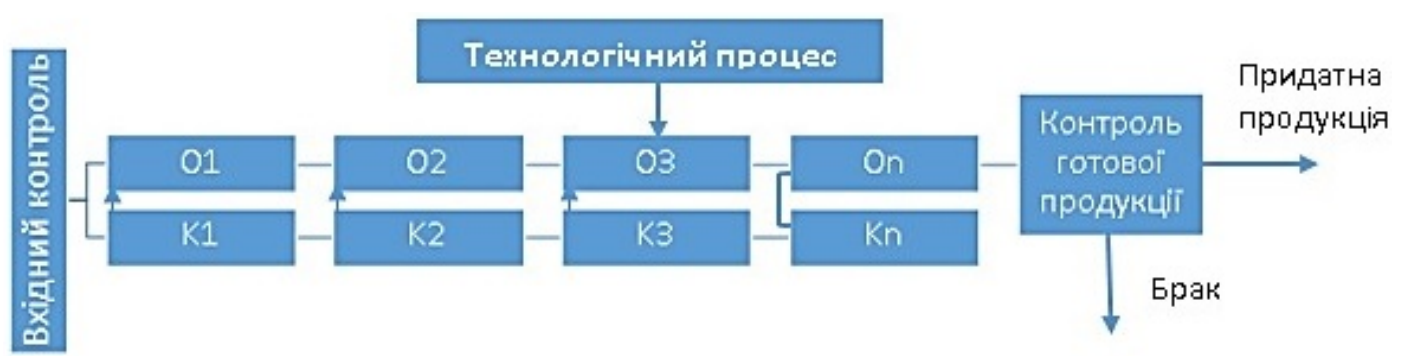

Рис. 1. Регулювання якості у процесі виробництва за допомогою статистичного контролю

O1, 02, О3 ... On - технологічні операції; К1, К2, К3, ... Кn - контроль на основі вибірок після виконання відповідних технологічних операцій

Джерело: [2, с. 124]

і консультанта 3 теорії управління якістю Е. Демінга, котрий у другій половині XX ст. застосував системний підхід до менеджменту якості. Систему управління якістю американський вчений трактував як систему управління підприємством в цілому. Е. Демінг вважав, що кожен об'єкт або явище $є$ певною системою, котра не може існувати без певної цілі.

Творчо розвинувши та збагативши ідеї американського вченого У. Шухарта, американський вчений Е. Демінг вперше розробив програму управління якістю, що складається 3 трактувань самого вченого та містить наступні положення: «14 принципів», «7 смертельних хвороб», «Труднощі та фральстарти», «Ланцюгова реакція», «Принципи постійного поліпшення (Цикл Демінга)».

Всесвітньо відомі «14 принципів» Е. Демінга передбачають: постійне прагнення до удосконалення якості товару чи послуг; застосування фрілософрії якості на підприємстві; незалежність підприємства від тотального контролю; відмову від постачальників неякісного товару 3 найнижчіми цінами; постійне вдосконалення сервісно-виробничої діяльності; використання сучасних методів навчання персоналу; розробку системи ефективного керівництва; використання ефрективних методів комунікації; організацію тісної співпраці між підрозділами; відсутність перекладання відповідальності менеджерів за низьку якість на робітників; відмову від кількісних норм оцінки; створення умов для можливості робітників вдосконалюватися та пишатися своєю роботою; чітке окреслення обов'язків керівництва щодо постійного поліпшення якості продукції чи послуг [3, с. 128-133].

Таким чином, аналізуючи усі 14 принципів Демінга, можна ствердити, що вони $є$ відмінними від традиційної думки про те, що якість $€$ своєрідним компромісом між споживачами та виробниками. 14 принципів Демінга утворюють цілісний комплекс, в якому відмова від будь-якої із складових може мати негативний вплив інші складові. Перелічені принципи спрямовують діяльність підприємств на довгострокову стабільну працю, керівники, в свою чергу, забезпечують умови для постійного вдосконалення роботи підприємств, орієнтуючись на інтереси та бажання людей. Сутність даної фрілософрії Е. Демінга полягає у тому, що шлях до досягнення високого рівня якості на підприємствах $є$ нескінченним, адже не існує межі досконалості.

Створення циклу Демінга (цикл PDCA). Широкої популярності у сорері менеджменту якості набув «Принцип постійного поліпшення» або Цикл Демінга. Передбачається, що якість закладається під час створення продукції чи послуг, а в момент їх споживання здійснюється оцінка якості. Для контролю якості зіставляються фрактичні та планові показники рівня якості продукції та послуг, таким чином, фракт можливості здійснення контролю якості свідчить про можливість управління нею. Під час перевірки показників якості можливо виявити існуючі відхилення від норми, що є сутністю контролю якості. У разі виявлення будь-яких відхилень здійснюється пошук причини їх виникнення та проводяться корегувальні дії для їх усунення, після чого здійснюється повторна перевірка скорегованих показників якості, співставляючи їх з показниками взятими за норму.

Таким чином, Цикл Демінга містить чотири етапи робіт стосовно управління якістю: Plan - планування робіт; Do - впровадження робіт; Check - перевірка виконаних робіт; Action - здійснення корегуючих дій [2, с. 138]. Цикл Демінга також має назву PDCA-цикл, враховуючи послідовність проведення етапів зазначених вище, їх можна подати у вигляді зображення циклінчного процесу (див. рис. 2). 


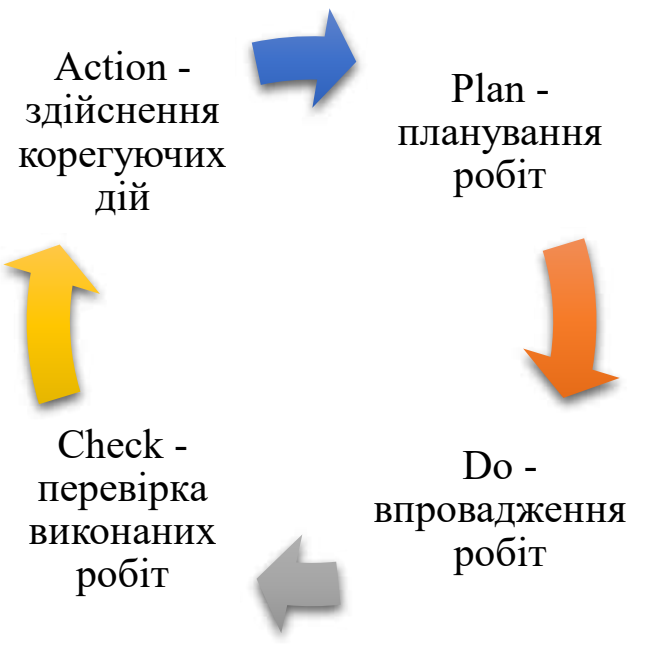

Рис. 2. PDCA-цикл (цикл Демінга)

Джерело: розроблено авторами на основі [2, c. 138-139]

Цикл повторюється на підприємстві до того моменту, доки фрактичні результати не відповідатимуть плановим, що може піддатися змінам адже потреби споживачів мають тенденцію змінюватись час від часу, таким чином даний метод $є$ основним для того щоб підприємство досягнуло необхідного рівня якості продукції та послуг [2, с. 138-139].

Використання американським фрахівецем в області якості Дж. Джураном контролю якості як інструментарію управління. Дж. Джуран американський фрахівець в області якості, академік Міжнародної академії якості у другій половині XX ст. першим обґрунтував необхідність переходу від контролю якості до управління якістю, як результат була розроблена «спіраль якості» («спіраль Джурана») - це позачасова просторова модель, вона визначила основні стадії робіт 3 управління якістю, що постійно розвивалися (див. рис. 3). «Спіраль якості» стала підґрунтям для великої кількості моделей управління якістю створених пізніше [2, с. 141].

Запровадження методів управління якістю японського фрахівця К. Ісікави. У другій половині XX ст. японський фахівець в галузі управління якістю Кауру Ісікава доопрацював методи статистичного контролю, створивши «сім інструментів контролю якості», також широке практичне застосування отримав його метод, що ґрунтується на аналізі причиннонаслідкових зав'язків під назвою «риб'яча кістка» або діаграма Ісікави. Зазначені методи орієнтуються на виявлення і поступове ліквідування причин появи відхилень у виробни-

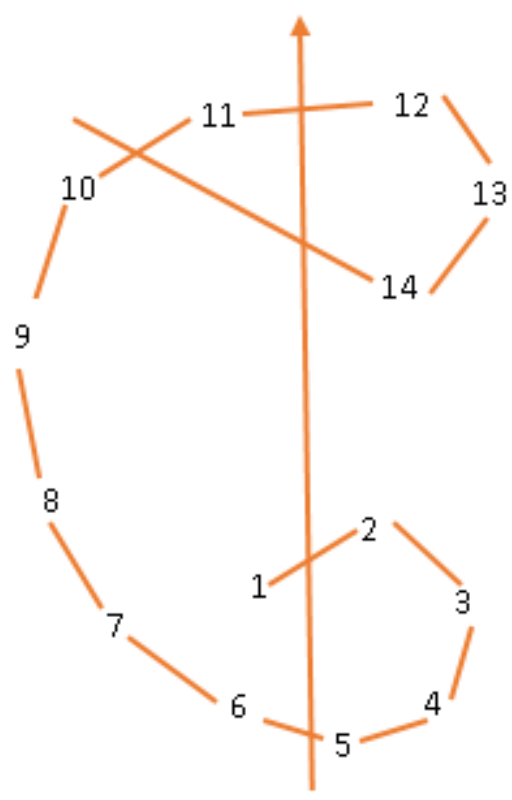

Рис. 3. Спіраль Джурана

1 - аналіз ринку; 2 - розробка проектного завдання; 3 - проектно-конструкторські роботи; 4 - формулювання технічних умов; 5 - розробка технологій та виробнича підготовка; 6 - здійснення матеріально-технічного забезпечення;

7 - створення пристроїв, інструментів, контрольновимірювальних засобів; 8 - виробництво;

9 - контроль за виробничими процесами; 10 - контроль за готовою продукцією;

11 - випробувальні заходи щодо робочих характеристик продукції; 12 - збут готової продукції; 13 - технічне обслуговування; 14 - аналіз ринку

$$
\text { Джерело: [2, с. 142] }
$$

цтві, що в подальшому сприяє підвищенню рівня якості та мінімізує вплив виявлених причин на роботу підприємства [2, с. 144-145].

Запровадження методів управління якістю японського фрахівця Г. Тагуті. Науковими дослідженнями статистичних методів планування, експерименту та контролю у сорері якості займався японський фрахівець в галузі управління якості Геніті Тагуті. Вчений розробив методи, що отримали назву Методи Тагуті або «інжиніринг якості», що стали принципово новим поглядом на поліпшення якості у другій половині XX ст.. В основі даних методів лежить одночасне поліпшення якості та мінімізація витрат, що пов'язані загальною характеристикою - фрункція витрат. Не зважаючі на існуючі недоліки методів у вигляді обмеженості цілей, відсутності чіткого взаємозв'язоку між ступенем задоволеності потреб споживачів та можливостями фрункціональної системи 3 цілями підприємства 
3 отриманням доходів, недостатньої увага ресурсам підприємства в системі управління якістю, низького рівня комунікаційних зв'язків на підприємстві, Г. Тагуті вдалося аргументувати ефективність застосування планування експерименту у сорері забезпечення якості та втілити дану методику у реальність.

Програма "ZD" американського фрахівця Ф. Кросбі. У 60-ті рр. ХХ ст. американський фрахівець у сорері якості Філіп Кросбі доклав зусиль для розвитку системного підходу в сорері якості, запропонувавши у 1964 р. програму, що отримала назву «ZD» або «Нуль дефектів» [2, с. 149]. Для більш глибокого розуміння необхідності застосування даної концепції потрібно розуміти сутність самого поняття «деоректу», що виникає під час сервісно-виробничої діяльності підприємств.

Відповідно до ДСТУ ISO 9000:2015 «Системи управління якістю. Основні положення та словник термінів» дефект визначається як: «невідповідність, пов'язана 3 передбачуваним або встановленим використанням», у свою чергу, невідповідність трактується як: «невиконання вимоги» [4, с. 14]. «Економічний словник» за редакцією вітчизняного науковця у галузі економіки Алексеєнко Л.М. містить таке визначення: «Дефект (defect, blemish; дефекm) - 1) недолік; 2) вада, гандж; 3) відсутність, брак» [1, с. 62].

Таким чином, десрект - це кожна окрема невідповідність продукції встановленим вимогам виявлена на стадії її виготовлення. Якщо не виконується якась 3 вимог нормативної документації щодо ознак продукції або один з показників якості продукції або її параметрів вийшов за межі встановленого граничного значення, означає, що одиниця продукції містить дефект. Дефекти, у свою чергу, підрозділяються на критичні, значні й малозначні, залежно від ступеня впливу кожного виду деоректу на еорективність і безпеку використання продукції з врахуванням її призначення, обладнання, показників якості, режимів і умов експлуатації [5].

Також, слід зазначити, що програма «Нуль дефектів» спирається на низку важливих концептуальних положень, а саме: чітке визначення керівництвом довгострокових цілей щодо поліпшення якості; наявність усвідомлення того, що загальна якість підприємства орормується також і за рахунок підрозділів невиробничого призначення, що спеціалізуються на наданні послуг; виявлення необхідності здійснення фрінансового аналізу забезпечення якості; фрокусування на попередженні виникнення десректів замість корегування існуючих відхилень; орієнтація на мінімізацію загальної кількості дефектів на виробництві; розуміння того, що виробник повинен забезпечувати виробництво продукції та надання послуг без деоректів, адже саме цього вимагає та очікує споживач.

Таким чином, стає зрозуміло, що в основі успішного фрункціонування програми «ZD» лежить принцип неприпустимості встановлення будь-якого рівня дефектності, що вважатиметься прийнятним, на початковому етапі виробництва (тобто рівень дефектності дорівнює нулю).

Розробка концепції комплексного управління якістю та всезагального контролю якості (TQM) американським експертом з контролю якості А. Фейгенбаумом. У свою чергу, 60-х рр. ХХст. широкої популярності набула концепція TQM (Total Quality Management) - комплексного управління якістю, яку розробив американський експерт 3 контролю якості А. Фейгенбаум, дана концепція стала новою фрілософрією у галузі управління підприємством. Саме А. Фейгенбаум був першим, хто ввів термін «комплексне управління якістю» [7, с. 61].

TQM має на меті досягнення довгострокового успіху шляхом максимального задоволення запитів усіх стейкхолдерів та ставить перед собою завдання постійного поліпшення якості шляхом регулярного аналізу результатів і коригування діяльності, прагнення до повної відсутності дефектів і зниження невиробничих витрат, забезпечення конкурентоспроможності, завоювання довіри всіх зацікавлених сторін за рахунок використання інноваційних технологій [6, с. 210]. Головне положення цієї концепції TQM - ідея про управління якістю, яка має охоплювати усі стадії створення продукції та усі рівні управлінської ієрархії підприємства під час реалізації технічних, економічних організаційних та соціально-психологічних заходів: «Комплексне управління якістю - це стиль керівництва, що започаткував нову культуру управління підприємством» [2, с. 151].

Отже, система TQM А. Фейгенбаума, що спирається на Цикл PDCA E. Демінга, «спіраль якості» Дж. Джурана, «інжиніринг якості» Г. Тагуті, програму «ZD» Ф. Кросбі, «сім інструментів контролю якості» К. Ісікави, на даному етапі розвитку управління якістю $\epsilon$ революцією у галузі менеджменту якості, хоча і має низку недоліків, адже при застосуванні цієї системи на підприємстві відбува- 
ється орієнтація на технічні проблеми, а не на поліпшення організаційної та економічної культури працівників. У той же час, фрілософрія концепції TQM не має єдиного трактування, адже на сприйняття даної концепції впливає як історичний проміжок часу так і менталітет, що притаманний кожній $з$ націй.

Підсумовуючи матеріали дослідження, можна виокремити наступні моделі управління якістю зображені на схемі 2:

Згідно схеми 2 менеджмент якості складається 39 провідних моделей всесвітньо відомих вчених. Можна ствердити, що Е. Демінг, Дж. Джуран, А. Фейгенбаум, Г. Тагуті, У. Е. Шухарт, К. Ісікава, Ф. Кросбі мали вирішальний вплив на сучасну теорію і практику забезпечення якості та лягли в основу концепції управління якістю ставши класичними.

Висновки. Проведене дослідження теорії та практики управління якістю в історичній ретроспективі, дає можливість зробити висновок про те, що кожен з етапів мав безпосередній вплив на подальші наукові розробки та концепції моделей розвитку менеджменту якості. Всесвітньо відомі вчені займалися створенням нових та удосконаленням вже існуючих моделей, заклавши фундамент класичного управління якістю на підприємствах.

Можна ствердити, що відбувся еволюційний рух від контролю якості на кінцевому етапі виробництва до здійснення управління якістю на всіх етапах життєвого циклу продукції (тотальний контроль), що істотно знижує ризик виготовлення дефектної продукції та виникнення небезпечних фракторів у процесі здійснення сервісно-виробничої діяльності операторами ринку товарів та послуг. Такий ефект, в свою чергу, позитивно впливає на скорочення фрінансових витрат та матеріальних ресурсів, що необхідні для усунення продукції та послуг не належного рівня якості, споживацькі потреби задовольняються в повній мірі, створюється привабливий імідж підприємства та формується комплекс конкурентних переваг для підприємства в умовах жорсткої конкуренції на сучасному ринку товарів та послуг.

Перспективним напрямком подальших досліджень $€$ розробка нових концепцій та методологій управління якістю, що є одним 3 головних завдань у ссрері якості, і наразі реалізується завдяки розробці та впровадженню

Розробка американським вченим Ф.Тейлором принципів наукового управління;

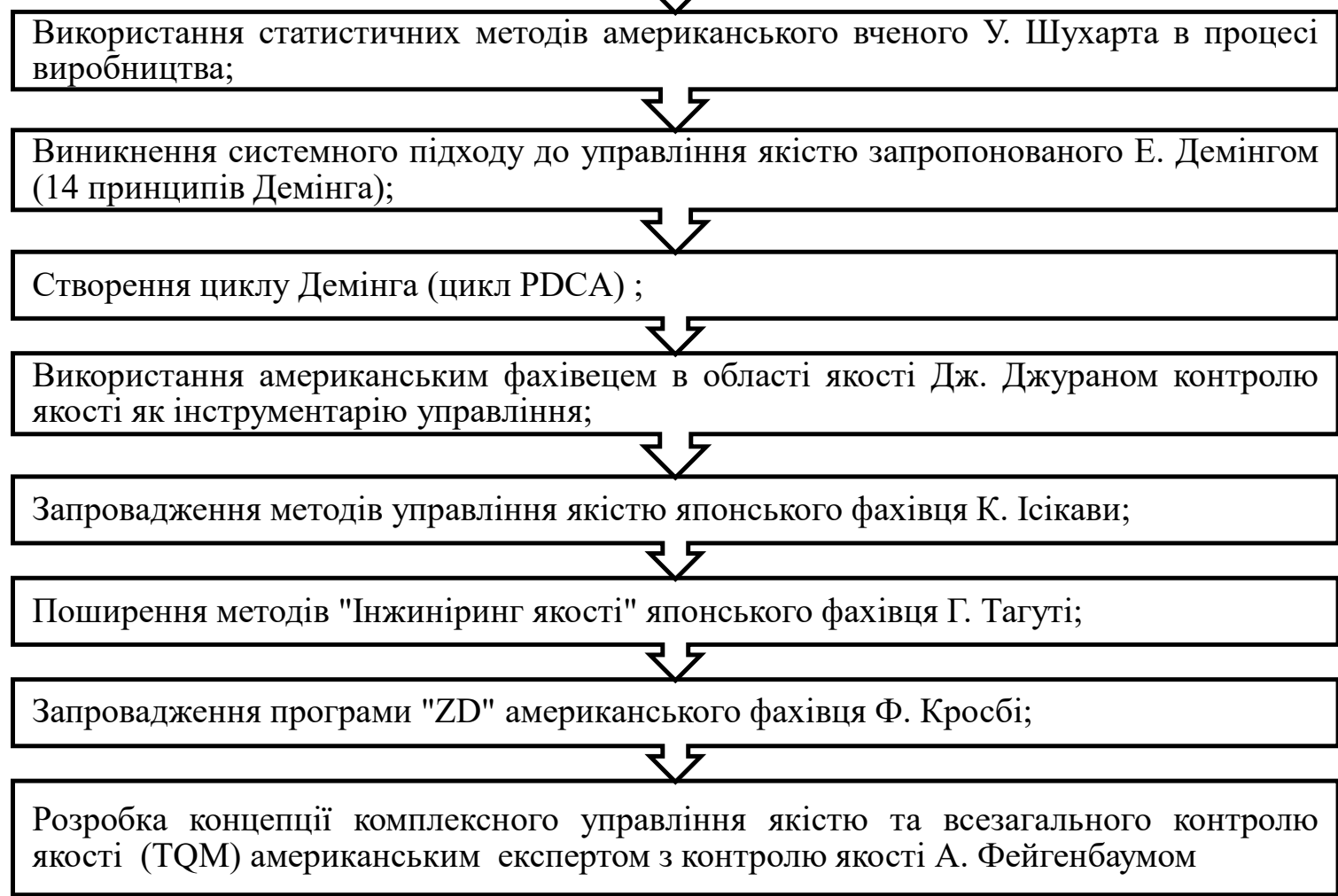

Схема 2. Моделі управління якістю Джерело: розроблено авторами на основі [2; 3] 
міжнародних стандартів серії ISO та інтегрованих систем управління якістю, в тому числі системи НАССР.

В умавах сьогодення найпоширенішим шляхом забепечення управління якістю на підприємствах є дотримання вимог міжнародних стандартів серії ISO, що охоплюють питання забезпечення сучасної методології менеджменту якості, систем екологічного менеджменту, гігієни та безпеки праці, соціальної відповідальності. Застосування даного методологічного підходу сприятиме ефективному управлінню якістю продукції та послуг, що $є$ одним з ключових векторів діяльності операторів ринку товарів та послуг. Нові концепції управління якістю, що створються 3 врахуванням сучасних тенденцій на ринку, базуються на стандартах ISO 9000, при цьому, ці стандарти $€$ універсальними та набули поширення в усіх галузях виробництва і сфрери послуг, завдяки чому оператори ринку мають можливість досягнути таких переваг як зростання стабільності підприємств, збільшення прибутку, поліпшення якості.

Також перспективним $є$ дотримання принципів системи управління безпечністю харчової продукції НАССР, що $€$ визнаною в усьому ствіті. Впровадження принципів системи НАССР, свідчать про зміну пріоритетів від оцінення кінцевого продукту до здійснення превентивного контролю в критичних точках процесу. Дана методологія позиціонується як дієвий інструмент для мінімізації появи харчової продукції з невідповідностями під час проведення технологічних процесів на підприємстві, а також ідентифрікації та усунення недоліків до того, як готова харчова продукція, що має невідповідності, нашкодить споживачу.

\section{СПИСОК ВИКОРИСТАНИХ ДЖЕРЕЛ:}

1. Алексеєнко Л.М., Олексієнко В.М., Юркевич А.І. Економічний словник: банківська справа, фоондовий ринок. Українсько-англійсько-російський тлумачний словник. Київ, 2000. С. 592.

2. Давидова О.Ю. Управління якістю продукції та послуг у готельно-ресторанному господарстві : підруч. Харків : Вид-во Іванченка І.С., 2018. 488 с.

3. Давидова О.Ю., Ладиженська Р.С., Писаревський І.М. Управління якістю продукції та послуг у готельноресторанному господарстві : навч. посіб. Харків : ХНАМГ, 2012. 468 с.

4. ДСТУ ISO 9000:2015. Системи управління якістю. Основні положення та словник термінів (ISO 9000:2015, IDT). [Чинний від 2015-12-21]. Вид. офіц. Київ : Держспоживстандарт України, 2016. 45c. URL: https://khoda.gov.ua/image/tsatalog/files/\%209000.pdf (дата звернення: 20.09.2021).

5. Козакова Н.В. Метрологічне забезпечення якості : метод. вказ. / уклад. Н.В. Козакова. Харків : НТУ «ХП|», 2017. $11 \mathrm{c}$.

6. Мельничук С.Д., Боровиков О.Я., Баль-Прилипко Л.В. Основи системи державного технічного регулювання : навчальний посібник. Київ : НУБіП, 2012. 283 с.

7. Фейгенбаум А., Фейгенбаум Д. Нова якість для XXI століття. Стандарти та якість. 2012. № 6. С. 59-62.

\section{REFERENCES:}

1. Alekseyenko L.M., Oleksiyenko V.M., Yurkevych A.I. (2000) Bankivs'ka sprava, fondovyy rynok [Economic dictionary: banking, stock market]. Kyiv: Maksymum. (in Ukrainian)

2. Davydova O.Yu. (2018) Upravlinnya yakistyu produktsiyi ta posluh u hotel'no-restorannomu hospodarstvi [Quality management of products and services in the hotel and restaurant industry]. Kharkiv: Vyd-vo Ivanchenka I.S. (in Ukrainian)

3. Davydova O.Yu., Ladyzhens'ka R.S., Pysarevs'kyy I.M. (2012) Upravlinnya yakistyu produktsiyi ta posluh $\mathrm{u}$ hotel'no-restorannomu hospodarstvi [Quality management of products and services in the hotel and restaurant industry]. Kharkiv: KHNAMH. (in Ukrainian)

4. Systemy upravlinnia iakistiu. Osnovni polozhennia ta slovnyk terminiv. DSTU ISO 9000:2015 (2016) Kyiv: Derzhspozhyvstandart Ukrainy. Available at: https://khoda.gov.ua/image/tsatalog/files/\%209000.pdf (accessed 20 September 2021).

5. Kozakova N.V. (2017) Metrolohichne zabezpechennya yakosti. metodychni vkazivky [Metrological quality assurance]. Kharkiv: NTU «KHPI». (in Ukrainian)

6. Mel'nychuk S.D., Borovykov O.Ya., Bal'-Prylypko L.V. (2012) Osnovy systemy derzhavnoho tekhnichnoho rehulyuvannya [Fundamentals of the system of state technical regulation]. Kyiv: NUBiP. (in Ukrainian)

7. Feyhenbaum A., Feyhenbaum D. (2000) Nova yakist' dlya XXI stolittya [Text New Quality for the XXI Century]. Standarty ta yakist' - Standards and quality, 6, 59-62. 